\title{
The Implementation of Tpack Framework Based Interactive Digital Learning for Cruise Vocational School (SMKP) Sinar Bahari Palembang
}

\author{
Hetty Meileni ${ }^{1, *}$ Indra Satriadi ${ }^{1,}$ Sony Oktapriandi ${ }^{1,}$ Desi Apriyanty ${ }^{1,}$ Dwi Harsyah \\ Prasetya $^{1,}$ Ade Prasetyo ${ }^{1,}$ Muhammad Faraby ${ }^{1}$
}

\author{
${ }^{1}$ State Polytechnic Of Sriwijaya \\ *Corresponding author. Email: hmeileni@gmail.com
}

\begin{abstract}
TPACK Framework (Technological Pedagogical Content Knowledge) is an ultra-important aspect for learning activities. It is not only about how to develop a good teaching process including giving and scoring assessment instruments but also understanding students' behavior and its psychological aspect. Pedagogy is about teaching in specific methods and strategies in order to know student's character deeper, resulted in specific teaching strategy for specific students. Before the pandemic, the only things achieved was only pedagogy and content, which are teaching materials taken from books. The transition period and adaptation of the pandemic often only presents content and technology. For example, the teacher only provides material, text or assignments via WhatsApp or Google Forms application with lack of interactions. Therefore, it is very important to include the three components of TPACK to achieve effective learning. The application of interactive digital learning is needed to raise students' motivation and enthusiasm for learning. The method used in this research is 4-D namely: Define, Design, Develop and Disseminate. The result shown that using interactive digital learning with netboard application, quizwhizzer.com and Qodlu are the best way to implement TPACK. Each student in cruise vocational school (SMKP) Sinar Bahari Palembang has fun learning with a better personal approach towards courses.
\end{abstract}

Keywords: TPACK, application, interactive, digital learning.

\section{INTRODUCTION}

The development of information technology in education sector is growing rapidly. It requires teachers to master technology and use it as a supporting media in learning activities. An example of the application of technology in learning activities is blended learning models. In this model, learning is not only focused on face-to-face activities in class but also uses web-based technology. Blended learning becomes an effective learning method because the atmosphere that is saturated with learning in class is aired with fun and interactive online learning activities. However, the use of web-based technology may be quite expensive because it requires electronic devices such as computers, laptop and smartphone. However, the other intended technology can also be in the form of teaching tools created by teachers themselves and still referring to the novelty of technology.

Effective online teaching practices promote conditions in which online learning occurs. Such practices are strengthened by effective course design principles, structures and practices. The identification and description of the skills required by teachers to create and facilitate an effective online course is an area that has been under investigation for some years $[1,2,3]$. The online teaching progress difficulty levels were also been identified as a factor which impacts on the quality of online courses and online teaching [4, 5]. Consensus about some of the best online teaching methodology can be summed up by De Gagne and Walters's suggestion that "a solid learner-centered environment and instructor visibility will lead to greater participation, teamwork, respect, and commitment from teachers and students" [6]. Although much effort and the findings of many studies have contributed to our understanding of effective online course design and effective online teaching practices, discussion continues regarding the impact of context and discipline on online teaching practices [7].

During pandemic era, TPACK Framework (Technological Pedagogical Content Knowledge) is a perfect methodology to be implemented in learning activities. Pedagogy is not only about how to develop the 
art of teaching or designing the completeness of process and assessment instruments in learning, but also a method that is applied for understanding students psychologically. There is a belief that a successful teacher is not a teacher who can only make his students smart but also successful in helping students find them true selves. Teacher must understand student's interests, talents and their characters. It is very important to present an effective learning experience. Effective learning is a learning that succeeds in achieving learning objectives of students as expected by the teacher. TPACK stands for Technological Pedagogical Content Knowledge. TPACK is a teacherbased framework to master 3 components: content, technology, and pedagogy.

Content itself contains of curriculum, materials, syllabus and materials related to what goals to be achieved in the learning process. Pedagogy is about how to teach students according to specific methods and strategies based on student's characters. Technology is the media used in the learning process. All those three components must be present. Before the pandemic, teachers only knew pedagogy and content because they teach based on printed books. The transition period and pandemic adaptation often only presents content and technology. For example, teacher only provides material then students should text and send assignments via WhatsApp or Google Forms application. These activities do not allow interaction both parties. Therefore, it is very important to present the three components of TPACK in order to produce effective learning.

Cruise Vocational School (SMKP) Sinar Bahari Palembang is a vocational school with 2 majors, namely Commercial Ship Nautica and Commercial Ship Engineering. The vision of the Sinar Bahari Cruise Vocational school is to become level IV marine education and training institution capable of producing professional, independent and highly competitive graduates in the future.

In this pandemic period, Sinar Bahari Cruise Vocational School carries out online learning for its students. This school has not implemented any special online learning media or applications that can be used for both teachers and students. The learning media used by teachers are Classroom and WhatsApp applications where WhatsApp is more widely used.

The problem is that the learning method used has not used TPACK yet. This is the background for researchers to implement TPACK at this school by developing interactive digital learning.

\section{RESEARCH METHODOLOGY}

The method used in this research is research and development. In research and development methods, there are several types of models. The model used in this research is 4-D model. The 4-D development model (Four D) is a learning device development model. The 4D development model consists of 4 main stages, namely: Define, Design, Develop and Disseminate. This method aims to produce products in the form of digital teaching materials. The end product would be tested for feasibility with validity and product trials to determine the extent to which the increase in learning motivation and student learning outcomes after learning using digital learning media [8].

Development procedure for research and development method is a research method used to produce certain products and test the effectiveness of these products. The research design used in this research is the research design of the 4-D model development (Four D Models). This includes 4 stages, namely the stage of defining, designing, developing and disseminating which can be explained as follows:

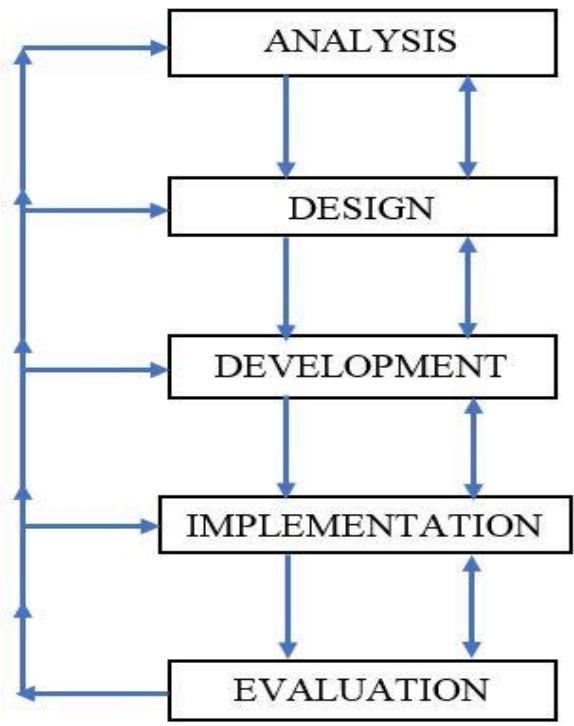

Figure 1. 4D learning system development model

\subsection{Define stage}

The definition stage is useful for determining and defining the needs in the learning process and collecting various information related to the product to be developed. This stage is divided into several steps, namely:

\subsubsection{Front-end Analysis}

The initial analysis was conducted to find out the basic problems in the development of learning media.

\subsubsection{Student Analysis (Learner Analysis)}

Student analysis is very important at the beginning of planning phase. Analysis of students is done by observing the characteristics of students. This analysis is carried out by considering the characteristics, abilities, and experiences of students, both as groups and individuals. The analysis of students includes the characteristics of academic ability, age, and motivation towards the subject. 


\subsubsection{Task Analysis}

Task analysis aims to identify the main tasks that will be carried out by students. Task analysis consists of an analysis of Core Competencies (KI) and Basic Competencies (KD) related to the material to be developed through learning media.

\subsubsection{Concept Analysis}

Concept analysis aims to determine the content of the material in the developed learning media. It is made in the learning concept map which will be used as a means of achieving certain competencies, by identifying and systematically compiling the main parts of the learning material.

\subsubsection{Analysis of Learning Objectives (Specifying Instructional Objectives)}

Analysis of learning objectives is carried out to determine indicators of learning achievement based on material analysis and curriculum analysis. By writing the learning objectives, researchers can find out what studies will be displayed in the learning media, determine the question grid, and finally determine how much the learning objectives are achieved.

\subsection{Stage of Design (design)}

After getting the problem from the definition stage, the next stage is the design stage. This design stage aims to design a learning media

\subsection{Development Phase (develop)}

This development stage aims to produce learning media that have been revised based on expert input and trials to students.

\subsection{Dissemination Stage (disseminate)}

After a limited trial and the instrument has been revised, the next stage is the dissemination stage. The purpose of this stage is to disseminate pop-up media. In this study, only limited dissemination was carried out, namely by disseminating and promoting the final product of learning media on a limited basis to the teachers of SMKP Sinar Bahari Palembang.

\section{DISCUSSION}

Technological Pedagogical Content Knowledge abbreviated as TPACK (previously abbreviated as TPCK) is a method to integrate technology in learning. A teacher is expected to have a good PCK in order to carry out an effective learning process [9]. Furthermore, the development of TPACK from PCK by teachers is urgently needed so that teaching with technology integration becomes effective. As in the development of PCK, prospective teachers or teachers are actively reviewing various methods to prepare teachers to teach with various technologies. The challenge is how to identify ways of learning prospective teachers in order to guide them in developing this knowledge. To illustrate of how far they have been involved in activities related to the knowledge component such as; technological knowledge (TK), content knowledge (CK), pedagogic knowledge (PK), content pedagogic knowledge (PCK), technology pedagogic knowledge (TPK), and content knowledge. technology (TCK), a new knowledge called TPACK. Figure 2 below is the TPACK framework and its components.

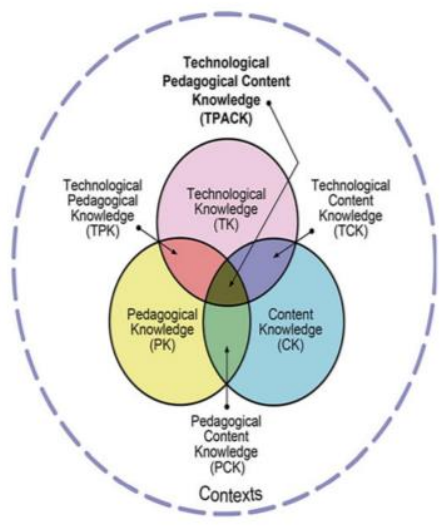

Figure 2. TPACK Framework

There are three components of the teacher's knowledge in TPACK skeleton model in Figure 1 above. They are subject material, pedagogy and technology. This model has three equally important intersections, namely the intersection between bodies of knowledge which are expressed as PCK (pedagogical content knowledge), TCK (technological content knowledge), TPK (technological pedagogical knowledge), and TPACK (technology, pedagogy, and content knowledge).

Technological Pedagogical Content Knowledge abbreviated as TPACK The TPACK model is an extension of the PCK concept by adding technology as a special type of teacher knowledge. There are three main components of teacher knowledge in the model, namely material content, technology and pedagogy. [2] described TPACK as follows:

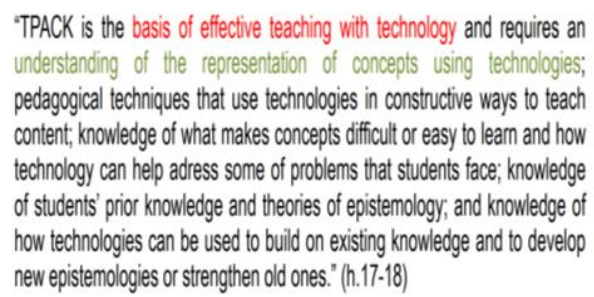

[10] TPACK defined as :

.... a way of thinking strategically while involved in planning, organizing, critiquing, and abstracting for specific content, specific student needs, and specific classroom situations while concurrently considering the multiude of twenty-first century technologies with the potential for supporting student 
In short, TPACK can be described as teacher's knowledge of when, where, and how to use technology, while guiding students in improving their knowledge and skills in a particular field of study. By using an adequate pedagogical approach [11]. Like PCK, the core of the TPACK model transform teacher knowledge which consists of four PCK components that support teaching with technology, namely:

1. A comprehensive conception of the purpose of integrating technology/ICT in teaching. How technology/ICT can encourage students to learn.

2. Knowledge of students' understanding, students' thoughts, and learning materials with technology/ICT integration.

3. Knowledge of the curriculum that integrates technology/ICT in learning. Associated with the curriculum components, teachers examine and apply various kinds of technology/ICT. Through this activity, they consider how concepts and processes in the context of a technology-rich environment are structured, structured, and assessed in the curriculum.

4. Knowledge of learning strategies and representations for learning activities with technology/ICT. This instructional knowledge focuses teachers on adapting their learning to assist students in learning certain technologies as they learn to use those technologies. They use certain representations with technology to achieve the learning objectives and needs of students in the classroom.

\subsection{Interactive Digital Learning}

Digital learning (digital learning) is a term that represents various educational strategies that are enhanced by the use of technology. Digital learning includes blended learning, flipped learning, personalized learning, and other strategies that rely on digital tools at both small and large levels [11]. The data show that simply giving students accesses to technology tools does not lead to better outcomes. However, smart integration of technology allows students to be actively involved with their ideas and their peers can actually enhance the learning experience. This becomes a strategic challenge related to countless intangible and abstract variables, including electronic devices, software, classroom practice, professional development, and collaboration among multiple stakeholders.

Digital learning is growing along with the development of technology. Digital learning can be developed for distance learning courses that are completely online, or combined with traditional classrooms as blended learning [12]. One of the most common problems in digital learning is that students are not involved in online activities. With the digital learning model, it will be easier for teachers, teachers and instructors to update their teaching and learning materials. It is their responsibility in accordance with the demands of the latest scientific developments, develop themselves or conduct research to improve their knowledge, and control the learning activities of students [13].

\subsection{Interactive Digital Learning Application}

The TPACK concept is closely related to the use of technology in providing lessons to students. Here are some examples of the use of applicable interactive digital learning applications.

\subsection{Netboard Application}

Netboard is a learning media that functions as a digital curator (loading selected content provided for students). In Netboard, users use many types of content. The form is similar to a blog. The differences are that it does not require students to log in in order to interact in netboard application.

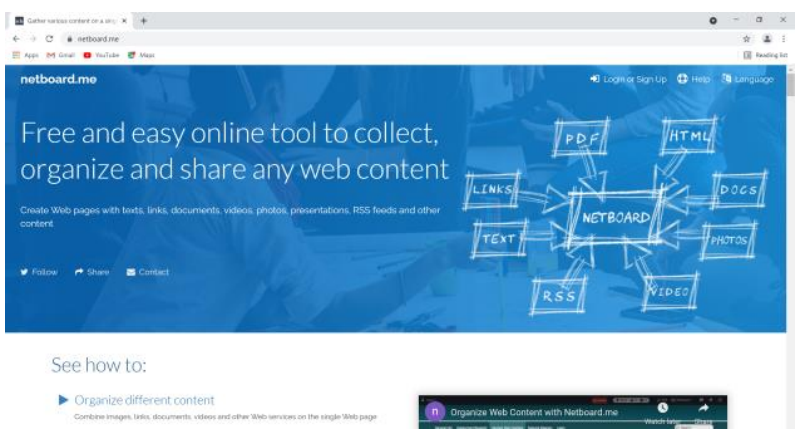

Figure 3. Netboard Application

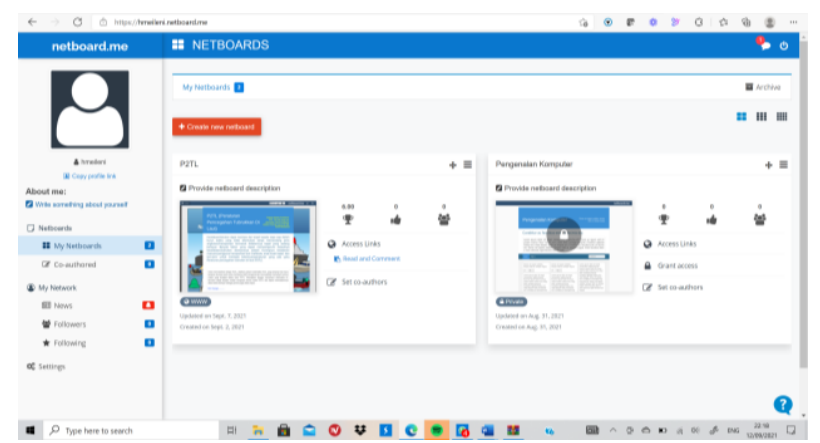

Figure 4. Uploading teaching materials to netboard

\subsection{App. Quizwhizzer.com}

Quizwhizzer implemented the concept of race, competition and racing system on a board game. If the student answers incorrectly, he will withdraw. However, if he wins, students may advance on that path. Students are asked to increase points. This digital tool can only be used $3 \mathrm{x} /$ month for free. This is perfect for asynchronous mode or as homework for students to do independently at home. 


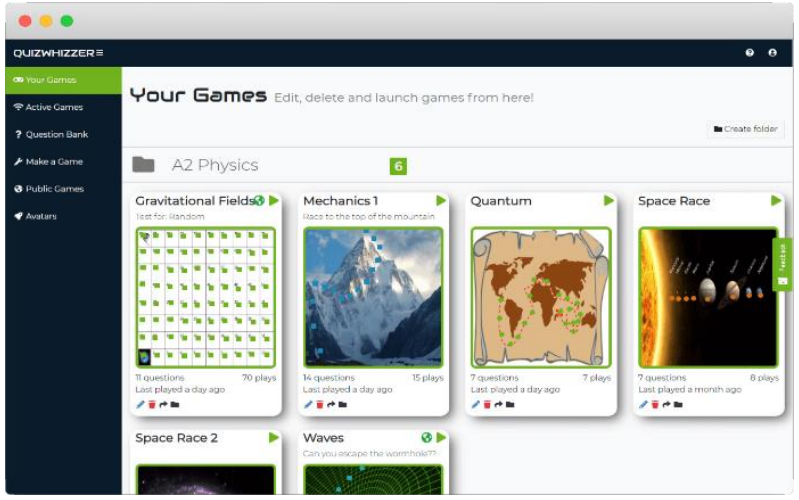

Figure 5. Quiz Application

\subsection{Qodlu}

Oodlu is a combination of quizzes and games application, students must fill out or answer new questions before then they can play games as rewards. In short, if student wants to play the game, he has to answer the questions first.
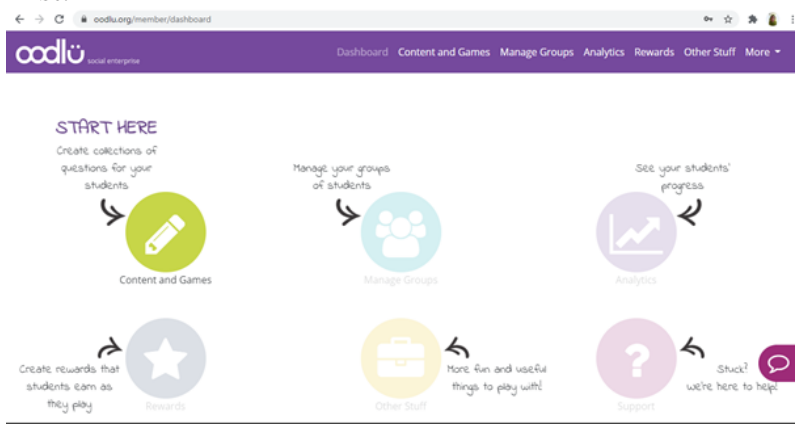

Figure 6. Qodlu

\section{CONCLUSION}

TPACK is a knowledge needed to integrate technology in learning. In TPACK framework model, there are three components of teacher knowledge, namely subject matter, pedagogy and technology. This model has three equally important intersections, namely the intersection between bodies of knowledge which are expressed as PCK (pedagogical content knowledge), TCK (technological content knowledge), TPK (technological pedagogical knowledge), and TPACK (technology, pedagogy, and content knowledge).

The design of attractive learning materials makes students learn more fun and not boring. Learning feels like playing by using various educational games, videos, and various learning resources provided by teachers.

\section{ACKNOWLEDGMENTS}

The researcher would like to thank the Principal of SMK Pelayaran Sinar Bahari who has helped and supported in providing data for the purpose of this research, and also to the teachers of SMK Pelayaran Sinar Bahari who have provided information related to learning in SMK Pelayaran Sinar Bahari.
The researcher also expresses gratitude to the Sriwijaya State Polytechnic which has provided funding assistance so that this research can be carried out properly and smoothly.

\section{REFERENCES}

[1] Herrington, J., \& Oliver, R. (2000). An instructional design framework for authentic learning environments Journal Educational Technology Research and Development 48(3), 23-48.

[2] Kerns, B., Elhouar, S., Sterling, M. J., Grant, J. M., McGowan, M., Rubash, A., ... Wolffe, R. (2005). Ten principles of effective teaching and practical examples for the classroom and Blackboard. Retrieved from http://www.forschungsnetzwerk.at/downloadpub/20 $\underline{05 \text { bradley univ RecommendedEffUseOfBb.pdf }}$

[3] Salmon, G. (2011). E-moderating: The key to teaching and learning online (3rd ed.). New York: Routledge.

[4] Northcote, M. (2008). Sense of place in online learning environments. Paper presented at the ASCILITE 2008: Hello! Where are you in the landscape of educational technology? Deakin University, Victoria.

[5] De Gagne, J. C., \& Walters, K. (2009). Online teaching experience: A qualitative metasynthesis. Journal of Online Learning and Teaching, 5(4), 577 599.

[6] Anderson, T., \& Elloumi, F. (2004). Theory and practice of online learning Retrieved from http://cde.athabascau.ca/online_book/contents.html

[7] Benson, R., \& Samarawickrema, G. (2009). Addressing the context of e-learning: using transactional distance theory to inform design. Distance Education, 30(1), 5-21.

[8] Eko Wahyu, Tyas Darmaningrat, Ahmad Holil Noor Ali, Radityo Prasetianto Wibowo, Hanin Maria Astuti : Utilization of Digital Learning Applications for Enrichment Learning in Surabaya City Middle Schools, 2018 National Seminar of Indonesian Information Systems.

[9] Sri Rahayu: Technological Pedagogocal Content Knowledge (TPACT): Integration of ICT in Science Learning in the 21st Century. Proceedings of the National Seminar on Science Education IX, 2017. 
[10] M.L. Niess. Knowledge needed for teaching with technologies- Call it TPACK. 2008.

[11] Shulman. Knowledge and teaching: Foundations of the new reform.

[12] Imam Fitri Rahmadi. Technological Pedagogical Content Knowledge (TPACK): 21st Century Teacher Knowledge Framework. Journal of Civics and Education Studies p-ISSN 2302-0865|e-ISSN 2621-346x.2019.

[13] Zhang, Y. (2015). Pedagogical Content Knowledge in Early Mathematics: What Teachers Know and How It Associates with Teaching and Learning. Dissertations. Loyola University Chicago. 